\title{
Jurist-Diction
}

Volume 4 No. 1, Januari 2021

\section{Pemungutan Pajak Pertambahan Nilai Terhadap Jual Beli Saldo Uang Elektronik}

\author{
Abhirama Adibrata Siswanto \\ abiramaadibrata@gmail.com \\ Universitas Airlangga
}

\begin{abstract}
How to cite:
Abhirama Adibrata

Siswanto 'Pemungutan

Pajak Pertambahan Nilai

Terhadap Jual Beli Saldo Uang

Elektronik' (2021) Vol. 4 No. 1

Jurist-Diction.

Histori artikel:

Submit 01 November 2020;

Diterima 10 Desember 2020;

Diterbitkan 5 Januari 2021.
\end{abstract}

DOI:

10.20473/jd.v4i1.24290

p-ISSN: 2721-8392

e-ISSN: $2655-8297$

\begin{abstract}
Value Added Tax is one of the biggest contributors to regional own-source revenue. Currently the taxation sistem is undergoing modernization, one of which is the sector affected by modernization method of payment for each transaction of goods and services that have started eliminating Conventional Money and experiencing a transition that is using Electronic Money. The government also supports the method because it follows modernization and provides more convenience than conventional money in general. However, with the ease in the transaction method, the collection of Value Added Tax on Electronic Money has not been carried out because of the Government's support and campaign to support transactions using electronic money so that it does not collect VAT on the sale and purchase of electronic money. This thesis entitled "Value Added Tax Collection of Electronic Money Transaction".

Keywords: Value Added Tax; Electronic Money's Transaction; Law Enforcement.
\end{abstract}

\begin{abstract}
Abstrak
Pajak Pertambahan Nilai merupakan salah satu penyumbang terbesar dalam pendapatan pusat. Saat ini sistem perpajakan mengalami modernisasi salah satunya sektor yang terkena dampak dari modernisasi adalah metode pembayaran atas setiap transaksi barang maupun jasa yang sudah mulai meniadakan Uang Konvensional dan mengalami transisi yaitu menggunakan Uang Eelektronik. Pemerintah juga turut mendukung metode tersebut karena mengikuti dengan modernisasi dan memberikan banyak kemudahan daripada uang konvensional secara umum. Namun dengan adanya kemudahan dalam metode transaksi tersebut pemungutan atas Pajak Pertambahan Nilai terhadap Uang elektronik masih belum dilakukan karena Dukungan dan kampanye Pemerintah yang mendukung transaksi menggunakan uang elektronik sehingga belum memungut PPN atas jual beli uang elektronik. Skripsi ini berjudul "Pemungutan Pajak Pertambahan Nilai Terhadap Jual Beli Uang Elektronik”.

Kata Kunci: Pajak Pertambahan Nilai; Jual beli Uang Elektronik; Penegakan Hukum.
\end{abstract}

Copyright $\odot 2021$ Universitas Airlangga

\section{Pendahuluan}

Teknologi dan Informasi merupakan pekerjaan dimana dalam sektor barang dan jasa sendiri terdapat banyak pekerjaan yaitu salah satunya sebagai Perusahaan 
Uang Elektronik. Perusahaan Uang Elektronik merupakan kegiatan Jual Beli barang dan Jasa yang dilakukan oleh Pengusaha terkait dengan Uang elektronik, dimana Objek Jual beli ini adalah Uang elektronik. Uang Eleektronik pada zaman sekarang sering digunakan dalam setiap metode transaksi barang maupun jasa pada setiap barang. Uang Elektronik pada zaman sekarang juga menggantikan dari metode pembayan konvensional yang menggunakan uang sebagai metode pembayaran yang lebih efisien dan cepat. Metode penggunaan uang elektronik pun juga didukung oleh Pemerintah seiring dengan Modernisasi. Perkembangan Teknologi dan Informasi tersebut juga memunculkan perdagangan barang dan jasa melalui sistem dalam jaringan (online) atau yang biasa disebut E-Commerce. E-commerce sendiri merupakan tempat jual beli dalam bentuk barang dan jasa yang diperjual belikan melalui Online. Selain itu dari perkembangan Teknologi dan Informasi juga terdapat perkembangan dari sector lain, yaitu didalam sector finansial.

Uang elektronik merupakan pengganti uang konvensional untuk bertransaksi berbasis online maupun transaksi konvensional. Uang elektronik juga memberikan kelebihan bagi penggunanya untuk memudahkan dalam bertransaki tanpa perlu membawa uang konvensional dan lebih mempercepat proses transaksi. Seiring dengan berjalannya waktu, penggunaan uang elektronik juga meningkat karena tingkat efisiensi waktu dan beberapa kelebihan yang dapat secara langsung dirasakan oleh pengguna uang elektronik. Dari peningkatan penggunaan uang elektronik itu sendiri memiliki dampak bagi perkembangan transaksi . Namun pemungutan pajak atas jual beli saldo tersebut mengalami permasalahan. Permasalahan yang dapat ditemui yaitu:

1. Permasalahan mengenai pemungutan pajak didalam jual beli saldo elektronik. Dimana pemungutan pajak jual beli saldo elektronik yang dilakukan mengalami permasalahan karena belum ada aturan yang jelas mengenai pemungutan jual beli saldo uang elektronik tersebut.

2. Permasalahan yang dihadapi bagi penegak hukum pajak dikarenakan belum adanya landasan yang jelas mengenai keabsahan dalam pemungutan pajak jual beli saldo uang elektronik itu sendiri. 
3. Belum adanya aturan yang mengatur teentang uang elektronik secara spesifik sebagai objek pajak pertambahan nilai karena uang elektronik merupakan metode bayar yang masih didukung pemerintah untuk beralih dari uang konvensional menjadi uang elektronik. selain itu transaksi jual beli uang elektronik masih hanya sebatas biaya administrasi yang dipungut oleh penjual elektronik semata.

Tipe penelitian yang dipakai adalah penelitian hukum normatif yaitu teknik atau prosedur dengan telaah yang berpedoman pada beberapa asas hukum. Kaidahkaidah hukum, maupun prinsip-prinsip hukum yang berkaitan dengan substansi peraturan perundang-undangan yang bersifat umum dan khusus, sehingga dapat menjawab atas isu hukum yang ada. ${ }^{1}$

\section{Ratio Legis Pemungutan Pajak Pertambahan Nilai Terhadap Jual beli Uang Elektronik}

Uang elektronik merupakan salah satu sumber pendapatan negara yang memberikan tambahan keuangan negara secara signifikan karena memberikan pemungutan pajak dari setiap transaksi elektronik juga untuk menjaga basis penerimaan pajak pemerintah. Penggunaan uang elektronik juga semakin digunakan oleh masyarakat untuk bertransaksi dari dalam maupun luar negeri secara massif Selain itu pemungutan atas jual beli uang elektronik juga memberikan tambahan anggaran dana kepada pemerintah pusat untuk membangun negara dan sebagai cadangan dana pemerintah sebagai kebutuhan yang akan datang baik secara darurat maupun rencana yang akan datang. Selain itu menurut Undang-Undang Nomor 28 Tahun 2007 tentang Ketentuan Umum dan Tata Cara Perpajakan, disebutkan bahwa pajak merupakan kontribusi yang bersifat wajib kepada negara yang terutang oleh orang pribadi atau badan yang bersifat memaksa berdasarkan undang-undang dengan tidak mendapatkan imbalan secara langsung dan digunakan untuk keperluan negara bagi sebesar-besarnya kemakmuran rakyat. Yang artinya pemungutan pajak

${ }^{1}$ Peter Mahmud Marzuki, Penelitian hukum edisi revisi (Kencana Pramedia Grup 2015).[60]. 
tersebut memberikan manfaat bagi masyarakat sendiri secara tidak langsung dan dapat dirasakan secara tidak langsung begitupun juga dengan uang elektronik yang memudahkan masyarakat dalam bertransaksi.

Pemungutan pajak telah diatur dalam Undang-Undang Dasar Negara Republik Indonesia tahun 1945 yang diatur dalam Pasal 23A sebagai Dasar dalam Pemungutan Pajak. sebagaimana dalam Pasal tersebut yang berbunyi "pajak dan pungutan lain yang bersifat memaksa untuk keperluan Negara diatur dengan undang-undang". Sehingga dalam pemungutan pajak memiliki sifat wajib bagi setiap warga Negara.

Pajak Pertambahan Nilai (PPN) adalah pajak yang dikenakan terhadap penyerahan atas impor Barang Kena Pajak, dan dapat dikenakan berkali kali setiap ada pertambahan nilai dari objek pertambahan nilai tersebut dan dapat dikreditkan. Dasar hukum PPn tertuang dalam Undang-Undang Nomor 8 tahun 1983 tentang pajak pertambahan Nilai dan atau penjualan atas barang mewah sebagaimana telah dirubah dalam Undang-Undang Nomor 42 tahun 2009.

\section{Subjek Pajak Pertambahan Nilai Terhadap Jual Beli Uang Elektronik}

Peraturan Perpajakan No. 18 Tahun 2000 mengenai Pajak Pertambahan Nilai memiliki banyak istilah atau pengertian-pengertian penting yang perlu diketahui dalam Pajak Pertambahan Nilai (PPN) hal ini dijelaskan dalam pasal 1, antara lain:

1. Pengusaha adalah orang pribadi atau badan yang dalam bentuk apa saja yang dalam lingkungan perusahaan atau dalam pekerjaan menghasilkan barang, mengimpor barang, mengekspor barang, melakukan usaha dagang, memanfaatkan barang tidak berwujud dari luar pabean, melakukan usaha jasa dari luar daerah pabean.

2. Pengusaha Kena Pajak (PKP) adalah orang atau badan dalam bentuk apapun yang dalam lingkungan pekerjaannya atau perusahaannya menghasilkan barang, mengimpor barang, mengekspor barang, melakukan usaha perdagangan atau melakukan usaha jasa yang dikenakan Pajak Pertambahan Nilai. ${ }^{2}$

2 Novi Darmayanti, 'Analisis Perhitungan Pajak Pertambahan Nilai (Ppn) Pada Cv. Sarana Teknik Kontrol Surabaya' (Jurnal Manajemen dan Akuntansi, 2012) diakses pada 13 April 2020. 
Sementara, orang pribadi yang memanfaatkan BKP/JKP di dalam daerah pabean Indonesia, juga merupakan subjek PPN. Namun, kewajiban subjek PPN yang memanfaatkan atau mengkonsumsi BKP/JKP di dalam daerah pabean ini hanya sebatas pada pembayaran PPN, yang umumnya harga yang dibayarkan oleh konsumen sudah termasuk pungutan PPN. Semua orang dapat dikatakan sebagai subjek PPN. Hal ini dapat dilihat dari sifat PPN yang merupakan pajak objektif, yang merupakan munculnya kewajiban pajak di bidang ditentukan oleh adanya objek pajak, seperti keadaan, peristiwa, atau perbuatan hukum yang dapat dikenakan pajak. Oleh karena itu, PPN tidak membedakan tingkat kemampuan konsumen dalam pengenaan pajak. Selain itu, sifat PPN yang merupakan pajak konsumsi dalam negeri juga membuat semua orang masuk dalam lingkup wilayah Indonesia menjadi subjek PPN. Karena, PPN dikenakan atas barang atau jasa yang dikonsumsi di dalam daerah pabean Indonesia.

Pengertian Subjek Pajak tersebut, subjek pajak yang dimaksud dalam penulisan ini adalah setiap pengusaha yang melakukan jual beli uang elektronik yaitu Setiap pribadi atau pengusaha yang melakukan transaksi jual beli uang elektronik, kemudian melalukan jual beli uang elektronik yang memiliki jumlah penjualan barang/jasa. Selain itu Subjek pajak yang dimaksud adalah setiap pengusaha uang elektronik yang wajib memungut atas PPN dari setiap transaksi jual beli elektronik.

Undang-Undang Nomor 42 Tahun 2009 menyebutkan bahwa subjek yang dikenakan objek PPN adalah setiap individu atau pengusaha yang melakukan jual beli. apabila masing-masing pihak telah sepakat terhadap objek atau barang yang diperjualbelikan sebagai objek perjanjian serta dalam hal ini telah terpenuhi syarat sahnya perjanjian dan masing-masing pihak menuangkannya dalam akta dan ditandatangani, maka secara sah dan meyakinkan perjanjian jual-beli tersebut dapat dijalankan menjadi undang-undang bagi mereka yang membuatnya (penjelasan Pasal 1338 KUHPerdata). ${ }^{3}$ PPN Indonesia Menerapkan Tarif Tunggal, dimana 10\% atas penyerahan Barang Kena Pajak atau Jasa Kena Pajak di dalam daerah pabean.

${ }^{3}$ Ahmadi Miru, Hukum Kontrak dan Perancangan Kontrak (Raja Grafindo Persada 2007).[127]. 
Abhirama Adibrata: Pemungutan Pajak Pertambahan...

Meskipun penerapan tarif tunggal akan semakin mempertajam dampak regresif, penerapan tarif tunggal juga digunakan untuk mengurangi dampak regresif PPN, Undang-Undang Nomor 42 Tahun 2009 mengenakan PPnBM di samping PPN atas komsumsi BKP yang Tergolong Mewah, tidak menggunakan diversifikasi tarif ${ }^{4}$. Memang, penerapan tarif tunggal memiliki sisi positif yaitu mudah di bidang pelaksanaan dan pengawasan.

Objek pajak pada Pajak Pertambahan Nilai sebagai pajak objektif wajib didahulukan sebelum menentukan subjek pajak. Dalam arti bahwa karakter Pajak Pertambahan Nilai ditentukan oleh eksistensi objek pajak sebagai lahirnya atas kewajiban pajak. PPN adalah Pajak Objektif Sebagai pajak objektif mengandung pengertian bahwa timbulnya kewajiban pajak di bidang PPN sangat ditentukan oleh adanya objek pajak. Kondisi subjektif subjek pajak tidak relevan. Sebab PPN tidak memerhatikan kondisi subjektif subjek pajaknya, sebagai pajak PPN menimbulkan dampak regresif. Regresifitas PPN mengandung pengertian bahwa semakin tinggi kemampuan konsumen, semakin ringan beban pajak yang dipikul.

Untuk mengurangi dampak regresif PPN tersebut, dalam hal konsumen yang berpenghasilan tinggi yang melakukan konsumsi Barang Kena Pajak yang Tergolong Mewah (PPnBM). Jadi pengenaan PPnBM disamping PPN bertujuan untuk mengurangi kesenjangan beban pajak antara konsumen yang berpenghasilan tinggi dengna konsumen yang berpenghasilan rendah.šcepPPN Indonesia Menerapkan Tarif Tunggal padais Undang-Undang Nomor 42 Tahun 2009 menerapkan tarif tunggal, yaitu 10\% atas penyerahan BKP atau JKP dalam daerah pabean Indonesia. Begitupun juga terhadap setiap transaksi yang dilakukan terhadap jual beli uang elektronik.

\section{Objek Pajak Pertambahan Nilai Terhadap Jual Beli Uang Elektronik}

Objek pajak yang diperjual belikan oleh Subjek Pajak yaitu Uang Elektronik sebagai Objek pajak. Uang Elektronik sendiri merupakan uang yang mempunyai karakteristik yang berbeda dengan pembayaran secara elektronik yang telah ada

${ }^{4}$ Terra Ben, 'Sales Taxation, The Case of Value Added Tax in The European Community' (Kluwer Law and Taxation Publisher, 1988) diakses tanggal 14 april 2020. 
sebelumnya, seperti contohnya adalah Internet banking dan Mobile Banking, kartu debit dan kartu kredit. Karena uang elektronik sendiri tidak selalu setiap pembayaran yang dilakukan dengan menggunakan transaksi uang elektronik memerlukan proses otorisasi dan tidak terikat secara langsung dengan rekening nasabah di bank (pada saat melakukan pembayaran tidak dibebankan sebab uang elektronik tersebut merupakan produk dimana sejumlah nilai telah terekam dalam alat pembayaran yang digunakan). ${ }^{5}$ Dijelaskan didalam Peraturan perundangundangan mengenai definisi uang elektronik dijelaskan menurut Pasal 1 angka 3 Peraturan Bank Indonesia Nomor 20/6/PBI/2018 Tentang Uang Elektronik, yaitu: Uang Elektronik (Electronic Money) adalah alat pembayaran yang memenuhi unsur-unsur sebagai berikut:

1. diterbitkan atas dasar nilai uang yang disetor terlebih dahulu oleh pemegang kepada penerbit;

2. nilai uang disimpan secara elektronik dalam suatu media seperti server atau chip;

3. digunakan sebagai alat pembayaran kepada pedagangyang bukan merupakan penerbit uang elektronik tersebut; dan d. nilai uang elektronik yang disetor oleh pemegang dan dikelola oleh penerbit bukan merupakan simpanan sebagaimana dimaksud dalam undang-undang yang mengatur mengenai perbankan.

Uang Elektronik bisa dikatakan sebagai barang tidak berwujud karena menurut pasal 503 BW menjelaskan mengenai konsep barang tidak berwujud adalah barang yang tidak memiliki tubuh. Jika melihat perumusan yang terdapat dalam BW, benda yang tidak berwujud walaupun benda tersebut tidak memiliki wujud, sebenarnya terdapat hak yang diletakkan atas benda yang berwujud. Dengan demikian, benda tidak berwujud menitik beratkan pada manfaat tertentu atas suatu benda tertentu yang memiliki wujud baik uang elektronik itu sendiri.

Definisi Uang Elektronik tersebut maka uang elektronik memiliki pengertian dan fungsi yaitu uang tunai yang bersifat non - fisik (cashless

${ }^{5}$ Mintarsih, 'Perlindungan Konsumen Pemegang Uang Elektronik (E-Money) Dihubungkan Dengan Undang-Undang Nomor 8 Tahun 1999 Tentang Perlindungan Konsumen'(Jurnal Wawasan Hukum, 2013) diakses tanggal 14 April 2020. 
money), yang dimana nilai uangnya berasal dari nilai uang yang telah disetor terlebih dahulu kepada penerbit, yang selanjutnya disimpan secara elektronik dalam suatu media elektronik berupa server atau kartu chip, yang berfungsi sebagai alat pembayaran non tunai kepada pedagang yang bukan penerbit uang elektronik yang bersangkutan. Nilai uang pada uang elektronik didapatkan dengan cara menyetorkan terlebih dahulu sejumlah uang kepada penerbit, baik secara langsung, maupun melalui agen-agen penerbit, atau dengan pendebitan rekening di bank. ${ }^{6}$

Dari pasal dan pengertian mengenai uang elektronik yang telah dijelaskan tersebut dapat dikatakan bahwa, segala transaksi yang dilakukan oleh Pengusaha kena pajak yaitu uang elektronik merupakan objek pajak, termasuk segala kegiatan jual beli uang elektronik itu sendiri. Oleh karena itu jual beli Uang Elektronik merupakan objek Pajak Pertambahan Nilai karena sesuai dengan penjelasan mengenai uang elektronik sebagai objek pajak menurut Undang-Undang Nomor 42 Tahun 2009 dan Uang elektronik sebagai benda tidak berwujud menurut KUHPerdata dan sebagaimana diatur dalam pasal tersebut.

Kewenangan pemungutan pajak, Pajak Pertambahan Nilai termasuk dalam Pajak Pusat / Pajak Negara. Bahwa wewenang pemungutan pajak pertambahan nilai berada pada pemerintah pusat yang pelaksanaannya dilakukan oleh Departemen Keuangan melaui Direktorat Jenderal Pajak. Hal tersebut berimplikasi terhadap Pengusaha kena pajak yang bersifat pasif, sebab dalam pemungutan pajak pertambahan nilai, wewenang untuk menentukan besarnya pajak terutang ada pada fiskus atau Pemerintah Pusat. ${ }^{7}$ Pemerintah Pusat mendapat wewenang untuk memungut pajak oleh Undang-Undang, yang wewenang pemungutannya ada pada pemerintah pusat dan hasil dari pemungutan PPN tersebut digunakan untuk membiayai pemerintah pusat dan pembangunan.

${ }^{6}$ Suharni, 'Uang Elektronik Ditinjau Dari Perspektif Hukum Dan Perubahan Sosial', (Jurnal Spektrum Hukum, 2018), diakses tanggal 14 April 2020.

7 Mardiasmo, Perpajakan, (Andi Yogyakarta 2001).[8]. 


\section{Wewenang Pemungutan Pajak Pertambahan Nilai Terhadap Jual Beli Uang Elektronik}

Wewenang dalam pemungutan pajak terutama pada Pajak Pertambahan Nilai diatur dalam Undang-Undang Nomor 42 Tahun 2009 pada pasal 1 angka 27 mengenai definisi pemungut pajak pertambahan nilai yaitu :

Pasal 1 Angka 27 :

"Pemungut Pajak Pertambahan Nilai adalah bendahara pemerintah, badan, atau instansi pemerintah yang ditunjuk oleh Menteri Keuangan untuk memungut, menyetor, dan melaporkan pajak yang terutang oleh Pengusaha Kena Pajak atas penyerahan Barang Kena Pajak dan/atau penyerahan Jasa Kena Pajak kepada bendahara pemerintah, badan, atau instansi pemerintah tersebut".

Bahwayang berhakmemungutpajakpertambahannilaiadalah badanPemungut PPN yang ditunjuk oleh Menteri Keuangan untuk memungut, menyetor, dan melaporkan pajak yang terutang oleh Pengusaha Kena Pajak atas penyerahan Barang Kena Pajak dan/atau penyerahan Jasa Kena Pajak. Sebagaimana dalam Pasal 1 Undang-Undang Nomor 42 Tahun 2009 tersebut yang dimaksud adalah Direktorat Jenderal Pajak. Melanjutkan pada Tugas dan wewenang Direktorat Jenderal Pajak sesuai amanat Peraturan Menteri Keuangan Nomor 234/PMK.01/2015 tentang Organisasi dan Tata Kerja Kementerian Keuangan adalah merumuskan dan melaksanakan kebijakan dan standardisasi teknis di bidang perpajakan. Yang dalam hal ini, Direktorat Jenderal Pajak selaku Pemungut PPN yang telah diamanatkan dalam Peraturan Menteri Keuangan tersebut, maka berdasarkan fungsinya wajib melakukan sebagai berikut:

1. perumusan kebijakan di bidang perpajakan;

2. pelaksanaan kebijakan di bidang perpajakan;

3. penyusunan norma, standar, prosedur, dan kriteria di bidang perpajakan;

4. pemberian bimbingan teknis dan evaluasi di bidang perpajakan; dan

5. pelaksanaan administrasi Direktorat Jenderal Pajak.

\section{Prosedur Pemungutan Pajak Pertambahan Nilai Terhadap Jual Beli Uang Elektronik}

Dalam pemungutan pajak juga didasarkan atas asas-asas keadilan didalam pemungutan pajak, antara lain: 


\section{a. Asas Equality}

Asas Equality merupakan asas dimana suatu Negara tidak diperbolehkan mengadakan diskriminasi antara Penanggung pajak terutang dengan Penanggung pajak terutang yang lain.pengenaan pajak terhadap subjek hendaknya dilakukan seimbang sesuai dengan kemampuannya. Antusiasme tiap Penanggung pajak terutang dalam memenuhi kewajiban pajaknya berdasarkan kemauan tiap individu atau Penanggung pajak terutang. ${ }^{8}$

b. Asas Certainty

Asas Certainty juga merupakan suatu asas yang menjelaskan bahwa pajak yang harus dibayarkan oleh Penanggung pajak terutang harus pasti untuk menjamin adanya kepastian hukum, baik mengenai subyek, objek, saat terutang pajak besarnya pajak dan saat pembayarannya.

Prinsip ini juga memperkuat bahwa bagaimanapun, setiap masyarakat menjadi pelaku usaha baik bertindak sebagai badan usaha ataupun orang pribadi wajib membayar PPN sesuai dengan prinsip-prinsip umum hukum pajak. pajak Pertambahan Nilai menganut pada Prinsip Akrual. Prinsip Akrual merupakan pihak terutang pajak terjadi pada saat penyerahan Barang Kena Pajak atau Jasa Kena Pajak meskipun pembayaran atas penyerahan tersebut belum diterima atau belum sepenuhnya diterima atau pada saat impor Barang Kena Pajak. Pajak yang dalam hal ini adalah Pertambahan nilai atas jual beli uang elektronik yang merupakan sesuatu yang melekat pada setiap individu yang melakukan aktivitas jual beli.

Berdasarkan Peraturan Menteri Keuangan Nomor 136/PMK.03/2012 tentang Perubahan atas Peraturan Menteri Keuangan Nomor 85/PMK.03/2012 tentang Penunjukan Badan Usaha Milik Negara untuk Memungut, Menyetor, dan Melaporkan Pajak Pertambahan Nilai atau Pajak Penjualan atas Barang Mewah, serta Tata Cara Pemungutan, Penyetoran, dan Pelaporannya, mekanisme pemungutan PPN adalah:

\footnotetext{
${ }^{8}$ Lubis Irwansyah, Taat hukum Pajak; (Mitra Wacana Media 2018).[90]
} 
1. penyerahan Barang Kena Pajak dan/atau penyerahan Jasa Kena Pajak;

2. penerimaan pembayaran dalam hal penerimaan pembayaran terjadi sebelum penyerahan Barang Kena Pajak dan/atau sebelum penyerahan Jasa Kena Pajak; atau

3. penerimaan pembayaran termin dalam hal penyerahan sebagian tahap pekerjaan. Meskipun ketentuan pajak konsumsi yakni Undang-Undang Nomor 42 Tahun 2009 Tentang Pajak Pertambahan Nilai Barang Dan Jasa Dan Pajak Penjualan Atas Barang Mewah. dapat diaplikasikan terhadap transaksi-transaksi uang elektronik tersebut, Undang-Undang Nomor 42 Tahun 2009 belum mengatur secara spesifik adanya aturan pelaksana terkait perdagangan secara daring (dalam jaringan), salah satunya produk digital yaitu uang elektronik.

Mekanisme pemungutan pajak terhadap barang uang elektronik dapat dilakukan melalui Peraturan Menteri Keuangan yang dalam kesimpulannya adalah Pengusaha Kena Pajak rekanan yang menerbitkan faktur pajak dan menerbitkan SSP atas setiap penyerahan BKP/JKP ke pemungut PPN. Yang kemudian Pelaporan PPN dilakukan setiap bulan dan laporannya disampaikan ke KPP tempat BUMN terdaftar. Perusahaan yang menjalankan usaha untuk jual beli uang elektronik wajib memungut Pajak Pertambahan Nilai atas setiap transaksi penjualan uang elektronik.

\section{Upaya Penegakan Hukum Pemungutan Pajak Pertambahan Nilai Terhadap Jual Beli Uang Elektronik}

Terdapat 2 macam kepatuhan yang perlu dilakukan oleh setiap pengusaha kena pajak yaitu kepatuhan Materiil dan Formil. $^{9}$ Kepatuhan Formil dapat dikatakan berhasil apabila pengusaha kena pajak memenuhi kewajiban membayar pajak terutangnya secara formal sesuai dengan ketentuan dalam Undang-Undang Perpajakan yang diatur. Sedangkan kategori Material dapat dikatakan berhasil jika secara substantif memenuhi semua unsure material tentang perpajakan.

Pemungutan pajak yang dilakukan oleh pemerintah atau fiskus dalam hal transaksi uang elektronik. Peredaran dan penggunaan uang elektronik juga semakin

9 Anwar Pohan, Pembahasan Komprehensif Perpajakan Indonesia Teori dan Kasus (Mitra Wacana Media Jakarta).[155]. 
luas dan mendapat dukungan sendiri dari pemerintah sebagai alternatif atau pengganti sistem pembayaran secara konvensional (tunai). Pengusaha kena pajak bagi pelaku usaha yang melakukan kegiatan jual-beli uang elektronik. Sehubungan dengan pajak, hierarki peraturan perundang-undangan mengenai pajak Diatur dalam Pasal 23A UUD Tahun 1945 yang menjelaskan bahwa Pajak dan pungutan lain yang bersifat memaksa untuk keperluan negara diatur dengan undang-undang. Hal ini merupakan landasan awal bagi Negara Indonesia untuk memungut pajak bagi setiap Pengusaha kena pajak yang dikenakan utang pajak. Yang selanjutnya diperluas kedalam berbagai peraturan- perundang undangan dibawahnya. Dan diikuti oleh perkembangan zaman, pengaturan pajak juga berubah-ubah sejalan dengan zaman yang ada. Menjalankan Upaya Preventif dalam rangka tercapainya kepatuhan hukum oleh Pengusaha Kena Pajak disektor pemungutan Pajak Pertambahan Nilai juga diterapkan fungsi controlling atau fungsi pengawasan.

Fungsi pengawasan dalam administrasi pajak adalah penjaminan bahwa aktivitas yang aktual sesuai dengan aktivitas yang telah direncanakan. Dalam menjalankan fungsi pengawasan yang dilakukan Direktorat Jenderal Pajak perlu dilakukan pemeriksaaan yang artinya serangkaian kegiatan untuk menghimpun dan mengolah data, keterangan, dan/atau bukti yang dilaksanakan secara objektif dan profesional yang bedasarkan standar pemeriksaan ${ }^{10}$. Yang dalam hal ini diatur menurut Undang Undang Nomor 28 Tahun 2007 tentang Ketentuan Umum Perpajakan. Upaya penegakan secara preventif yang dapat dilakukan oleh pemerintah yang dalam hal ini adalah Direktorat Jenderal Pajak.

Pengaturan mengenai pajak Pertambahan Nilai dan Peraturan Bank Indonesia tentang uang elektronik, pelaku usaha yang dalam hal ini adalah Pengusaha barang dan jasa uang elektronik sebagai Pemungut PPN yang melakukan kegiatan jual beli uang elektronik dan diawasi oleh Bank Indonesia merupakan tindakan preventif yang dilakukan oleh bank Indonesia dalam rangka menjaga kestabilan dan kelancaran uang elektronik yang beredar di masyarakat. Diatur dalam pasal

\footnotetext{
${ }^{10}$ Anwar Pohan, Op.Cit.[95]
} 
67 hingga pasal 73 Peratuan Bank Indonesia tentang Uang Elektronik. Dalam Bab 6 tersebut mengatur tentang hak dan kewajiban Bank Indonesia untuk melakukan Pengawasan. Pengawasan yang dilakukan oleh Bank Indonesia yaitu melakukan Pengawasan terhadap peredaran lalu lintas uang elektronik. Pengawasan lalu lintas tersebut memiliki tujuan yaitu sebagai Serta Penyelenggaraan Kegiatan Usaha barang dan jasa oleh pegusaha Uang elektronik sebagai pemungut PPN.

Pengawasan pemungutan pajak yang dilakukan oleh pemerintah Pusat yang dalam hal ini adalah Direktorat Jenderal Pajak yang berkaitan dengan Pungutan Pajak Pertambahan Nilai . Upaya Preventif dapat juga melalui upaya pemeriksaan demi mencapai kepatuhan didalam melakukan kewajiban perpajakan. Hal ini diatur dan dapat Dilihat dari Keputusan Menteri Keuangan Republik Indonesia Nomor 545/KMK/04/2000 dalam Pasal 2 Tentang Tata Cara Pemeriksaan Pajak yang menjelaskan mengenai Pemeriksaan :

Pasal 2:

"Serangkaian kegiatan untuk mencari, mengumpulkan dan mengolah data dan atau keterangan lainnya untuk menguji kepatuhan pemenuhan kewajiban perpajakan dan tujuan lain dalam rangka melaksanakan ketentuan peraturan perundang-undangan perpajakan"

Wewenang Direktur Jenderal Pajak untuk melakukan pemeriksaan diatur didalam Peraturan Menteri Keuangan Nomor 234/PMK.01/2015 tentang Organisasi dan Tata Kerja Kementerian Keuangan yang menyatakan bahwa Direktorat Jenderal Pajak melakukan pemeriksaan untuk menguji kepatuhan kewajiban perpajakan dan untuk tujuan lain dalam rangka melaksanakan ketentuan peraturan perundang-undangan perpajakan. Selain itu Direktorat Jenderal Pajak wajib memberikan pelayanan, penyuluhan, dan hubungan masyarakat, hal ini terdapat pada pasal 5 Peraturan Menteri Keuangan Republik Indonesia Nomor 234 /Pmk.01/ 2015 Tentang Organisasi Dan Tata Kerja Kementerian Keuangan yang dimana Kementerian Keuangan yang diamanatkan oleh Direktorat Jenderal Pajak untuk wajib menjalankan fungsi sesuai yang telah tercantum. Selain itu Direktorat Jenderal Pajak wajib menjalankan fungsi pengawasan atas pelaksanaan tugas di lingkungan Kementerian Keuangan. 
Upaya Represif dalam hal ini dilakukan oleh 2 lembaga pemerintah didalam 2 sektor yang berbeda, yang pertama adalah lembaga Direktorat Jenderal Pajak yang menjalan fungsinya didalam mengatur Sektor Pajak. Dan lembaga yang kedua adalah lembaga Bank Sentral yaitu Bank Indonesia. Bank Indonesia menjalankan fungsi mengatur didalam sektor Uang elektronik yang terbit di masyarakat. Didalam menajalankan fungsinya, kedua lembaga tersebut diberikan wewenang didalam peraturan yang berbeda. Bank Indonesia dalam menjalankan upaya represif dan dalam rangka menjaga lalu lintas uang elektronik sebagaimana diatur dalam Pasal 74 Peraturan Bank Indonesia tentang Uang Elektronik ayat (1) huruf a sampai c, dapat melakukan :

Pasal 74 ayat (1) huruf

a. Teguran,

b. Denda,

c. Penghentian sementara sebagian atau seluruh kegiatan Uang Elektronik dan/atau jasa sistem pembayaran lainnya; dan/atau d. pencabutan izin sebagai Penyelenggara dan/atau Penyelenggara Jasa Sistem Pembayaran lainnya.

Menjalankan Upaya Penegakan Represif yang dilakukan oleh Direktorat Jenderal Pajak, berwenang melakukan Penagihan PPN kepada setiap Pengusaha kena pajak. Dijelaskan bahwa Pengertian Penagihan pajak diatur didalam pasal 1 angka 9 Undang-Undang No.19 Tahun 1998 sebagaimana telah diubah dengan UndangUndang No. 19 tahun 2000 tentang penagihan pajak secara Paksa, yang berbunyi :

Pasal 1 Angka 9:

"Serangkaian tindakan agar penanggung pajak melunasi utang pajak dan biaya penagihan pajak dengan menegur atau memperingatkan, melaksanakan penagihan seketika dan sekaligus, memberitahukan surat paksa, mengusulkan pencegahan, melaksanakan penyitaan, melaksanakan penyanderaan, menjual bang yang disita".

Penagihan pajak yang diatur didalam pasal diatas merupakan bentuk upaya Represif yang dilakukan oleh Direktorat Jenderal Pajak kepada pengusaha kena pajak. Hal ini dapat dilihat dari wewenang yang diberikan yaitu Memperingatkan, melaksanakan penagihan seketika dan sekaligus. 


\section{Kesimpulan}

Pengusaha Kena pajak yang dalam halnya merupakan pengusaha atau orang pribadi yang melakukan transaksi jual beli uang elektronik wajib, dimana penjual atau pengusaha wajib melakukan pemungutan Pajak Pertambahan Nilai. Hal ini dikarenakan sesuai dengan UU Ketentuan Umum dan Tata Cara Perpajakan serta Undang-Undang tentang Pajak Pertambahan Nilai, Uang elektronik merupakan objek PPN. Upaya penegakan pemungutan Pajak Pertmbahan Nilai Terhadap Jual beli Uang Elektronik maka dapat disimpulkan bahwa terdapat 2 tindakan yang dilakukan oleh kedua lembaga didalam sektor yang berbeda. Tindakan pertama yaitu tindakan preventif yaitu upaya pencegahan.

Dimana didalam upaya preventif tersebut dilakukan oleh Bank Indonesia dan Direktorat Jenderal Pajak. Bank Indonesia memberikan tindakan preventif berupa pengawasan terhadap arus lalu lintas uang elektronik yang terbit didalam masyarakat, diatur dalam Peraturan Bank Indonesia Nomor 20/6/PBI/2018. Begitupun dengan Direktorat Jenderal Pajak yang memiliki wewenang didalam pemeriksaan pajak.

\section{Daftar Bacaan}

\section{Buku}

Ahmadi Miru, Hukum Kontrak dan Perancangan Kontrak (Raja Grafindo Persada).

Anwar Pohan, Pembahasan Komprehensif Perpajakan Indonesia Teori dan Kasus (Mitra Wacana Media).

Lubis Irwansyah, Abidah Sari Lubis ,Taat hukum Pajak (Mitra Wacana Media).

Mardiasmo, Perpajakan, (Andi Yogyakarta).

Marzuki, Peter Mahmud, Penelitian hukum edisi revisi, (Kencana Pramedia Grup).

Terra Ben, Sales Taxation, The Case of Value Added Tax in The European Community (Kluwer Law and Taxation Publisher).

\section{Jurnal}

Mintarsih, 'Perlindungan Konsumen Pemegang Uang Elektronik (E-Money) Dihubungkan Dengan Undang-Undang Nomor 8 Tahun 1999 Tentang 
Abhirama Adibrata: Pemungutan Pajak Pertambahan...

Perlindungan Konsumen’(2013) Jurnal Wawasan Hukum.

Novi Darmayanti, 'Analisis Perhitungan Pajak Pertambahan Nilai (Ppn) Pada Cv. Sarana Teknik Kontrol Surabaya', (2012) Jurnal Manajemen dan Akuntansi .

Suharni, 'Uang Elektronik Ditinjau Dari Perspektif Hukum Dan Perubahan Sosial' (2018) Jurnal Spektrum Hukum.

\section{Perundang-undangan}

Undang-Undang Nomor 19 Tahun 2000 tentang Perubahan Atas Undang-Undang Nomor 19 Tahun 1997 tentang Penagihan Pajak dengan Surat Paksa(Lembaran Negara Republik Indonesia Nomor 3987).

Undang-Undang Nomor 42 Tahun 2009 tentang Perubahan Ketiga Atas UndangUndang Nomor 8 Tahun 1983 Tentang Pajak Pertambahan Nilai Barang Dan Jasa Dan Pajak Penjualan Atas Barang Mewah. (Lembaran Negara Republik Indonesia Nomor 5069).

Peraturan Menteri Keuangan Republik Indonesia Nomor 37/PMK.03/2015 Tentang Penunjukan Badan Usaha Tertentu Untuk Memungut, Menyetor, Dan Melaporkan Pajak Pertambahan Nilai Atau Pajak Pertambahan Nilai Dan Pajak Penjualan Atas Barang Mewah, Serta Tata Cara Pemungutan, Penyetoran, Dan Pelaporannya.(Berita Negara Negara Republik Indonesia Tahun 2015 Nomor 345).

Peraturan Bank Indonesia Nomor 20/6/PBI/2018 Tentang Uang Elektronik (Tambahan Lembaran Negara Republik Indonesia Nomor 6203). 